Nloma 2015, 33(2), 107-117

Revista de Psicologia, Ciències de l'Educació i de l'Esport

ISSN: $1138-3194$

Copyright () 2015

www.revistaaloma.net

\title{
Cross-national validation of the resources depletion-recovery model: An empirical study of Spanish and British theme park employees
}

\author{
Cristina Quinones ${ }^{1}$, Raquel Rodríguez-Carvajal ${ }^{2}$, Mark D. Griffiths ${ }^{3}$ \& Nicholas Clarke \\ ${ }^{1}$ Open University Business School, (UK), ${ }^{2}$ Autonoma University of Madrid (Spain) \\ ${ }^{3}$ Nottingham Trent University (UK); ${ }^{4}$ School of Management, University of Southampton (UK)
}

Received: 16-4-2015

Accepted: 4-9-2015

Cross-national validation of the resources depletion-recovery model: An empirical study

Summary. Surface acting (SA) refers to the strategy whereby front-line employees hide their own emotions and fake those required of them within customer service transactions. Although researchers have associated SA with burnout, evidence now suggests that this could be an indirect relationship. Building on the Conservation of Resources theory, it was hypothesised that the combined effect of emotional effort and lack of rewarding interactions with customers triggered by SA would explain the strong association between SA and burnout (Studies 1 and 2). Furthermore, building on psychological recovery literature, it was hypothesised that the effort invested in SA would be a weaker predictor of front-line employees' burnout in cases when they reported higher levels of recovery ability as opposed to lower levels (Study 2). A cross-national and cross-sectional design was used, and participants were theme park employees from UK (Study 1, $N_{U K}=204$ ) and Spain (Study 2, $N_{\text {Spain }}=211$ ). The explanatory role of emotional effort and rewarding interactions was supported, and the buffering effect of recovery ability was confirmed. Strategies aimed at minimising burnout risk for employees who deal with customers on a regular basis in these countries are discussed.

Keywords: surface acting; emotional effort; rewarding interactions; burnout; cross-national

Validació transnacional del model de recuperació de recursos desgastats: Un estudi empíric d'empleats espanyols i britànics de parcs temàtics

Resum. L'actuació superficial (AS) es defineix com una estratègia en què els empleats de cara al públic amaguen les seves veritables emocions i simulen les emocions que s'esperen d'ells en els seus papers d'atenció al client. Encara que és veritat que investigadors anteriors s'han associat l'actuació superficial amb l'esgotament laboral, l'evidència col-leccionada de moment suggereix que aquesta relació pot ser indirecta. Basat en la Teoria de la Conservació de Recursos, es va plantejar la hipòtesi que l'efecte cumulat de l'esforç emocional i la manca d'interaccions gratificants amb els clients, provocats pel recurs a AS, explicarien l'associació forta entre AS i esgotament laboral (Estudis 1 i 2). A més, basat en la literatura psicològica sobre la recuperació, es va plantejar la hipòtesi que l'esforç requerit per AS determinaria en menor grau l'esgotament dels empleats de cara al públic en els casos en què s'atribuïen nivells més alts de capacitat de recuperació que en els casos de nivells més baixos (Estudi 2). Es va emprar un model transnacional i transversal, $i$ els participants van ser empleats de parcs temàtics del Regne Unit (Estudi 1, $N_{U K}=204$ ) i Espanya (Estudi 2, $N_{\text {Spain }}=211$ ). Es va trobar evidència del paper explicatiu de l'esforç emocional $i$ les interaccions gratificants, $i$ es va confirmar l'efecte amortidor de la capacitat per a la recuperació. Es comenten les estratègies dissenyades per minimitzar el risc d'esgotament laboral per als empleats que treballen de cara al públic en aquests països.

Paraules clau: actuació de superfície; esforç emocional, interaccions gratificants; esgotament laboral; transnacional

Correspondence

Cristina Quinones

Open University Business School, Open University, Walton Hall,

Milton Keynes, MK7 6AA, United Kingdom.

email: cristina.quinones@open.ac.uk 


\section{Introduction}

Appearing cheerful and remaining calm when dealing with a challenging customer, are just two examples of the emotionally laden work that front-line employees in the leisure and tourism industry engage in on a daily basis (e.g. Bozionelus \& Kiamou, 2008). Since employees may not always feel the emotions they have to display, they either fake these emotions (i.e., Surface Acting [SA]), or attempt to feel the emotions they have to express in order to appear more genuine (i.e., Deep Acting [DA]). Whether employees engage in SA or DA appears to be critical with regards to how these strategies affect their psychological and physical wellbeing. Researchers usually associate DA with positive outcomes such as professional efficacy and job satisfaction (e.g., Hülshegera \& Schewe, 2011). In contrast, SA is linked to burnout, a chronic stress syndrome comprised of emotional exhaustion, cynicism and low professional efficacy (e.g., Karatepe \& Uludag, 2008). However, increasing evidence suggests that the relationship between SA and burnout may be indirect. Consequently, the mechanisms that contribute to burnout when individuals fake their emotions to meet role requirements should be identified and explained (Goodwin, 2011). Understanding these mechanisms is crucial to minimise the risk of burnout in front-line leisure employees (Karatepe \& Uludag, 2008). In addition to the impairment of employee wellbeing, burnout is associated with a range of negative organisational outcomes including low productivity, absence from work, and desire to leave the organisation (Han, Bonn \& choo, 2016; Hobfoll \& Shirom, 2001; Guy, Newman \& Mastracci, 2014).

According to the Conservation of Resources Theory (COR) (Hobfoll \& Shirom, 2001), individuals invest resources in response to environmental demands. If, over time, they do not recover these resources, there is a high likelihood of burnout (Brotherdige \& Lee, 2002). When demands consist of displaying appropriate emotions to customers (i.e., display rules), employees invest their resources in ensuring that their emotions match those required by their occupational role (Grandey, Fisk, \& Steiner, 2005; grandey, 2015). In line with COR, it is expected that employees who fail to recover the effort they exert in managing their emotions through satisfactory interactions with customers will eventually experience burnout. Additionally, psychological recovery studies suggest that employees can also recover resources that they expend at work through unrelated enjoyable activities outside work. For instance, if one spends too many hours in front of the computer for work-related purposes, it is unlikely that completing chores requiring the use of IT after work will lead to effective recovery (e.g., Sonnentag \& Fritz, 2007). Instead, engaging in activities that do not involve the same psychological systems, such as practising physical exercise, socialising or meditating, is more likely to enable daily recovery. Thus, researchers have found that both engaging in activities that help employees relax in their spare time and their ability to detach from work function to restore their energy resources and prevent stress accumulation (Sonnentag \& Fritz, 2007). In view of this, individuals' ability to engage in recovery experiences (as a potential moderator of the effort that occurs with meeting the job's emotional requirements) is also tested.

In short, with the resource depletion-recovery model developed in this study, the present authors aimed to clarify how burnout unfolds in individuals who frequently engage in SA in order to cope with the emotional requirements of their job. These findings should contribute to developing focused interventions that minimise the resources depletion process that occurs as a result of work-related emotion regulation. Since a cross-national validation approach using British and Spanish samples was adopted, the study's findings allow for a greater level of generalisation than previous studies which have been either too reliant on AngloSaxon samples, and/or used a single-country for their model testing.

\section{Theory and hypothesis}

The Conservation of Resources (COR) theory builds on classic stress and motivational theory to offer a dynamic model that explains how burnout develops (Hobfoll \& Shirom, 2001). According to COR, individuals strive to achieve a balance between the resources they invest and the resources they receive as a result of their effort. A state of energy depletion will eventually arise if, in response to environmental demands, individuals simultaneously maintain a high level of resource investment and fail to recover these resources. Displaying the emotions that the job requires is a specific work demand that researchers associate with burnout in customer service employees (e.g., Grandey, Rupp \& Brice, 2015). In particular, engaging in SA to meet display rules consistently correlates with burnout in both cross-sectional studies (e.g., Brotheridge \& Lee, 2003) and experimental studies (e.g., Goldberg \& Grandey, 2007). However, it should be noted that some studies report weaker associations between these variables. For example, Zammuner and Galli (2005) confirmed the negative impact of SA on burnout in an Italian sample of service employees, yet the effect was relatively small. Similarly, Zerbe (2000) did not find a significant correlation between SA and emotional exhaustion in a sample of flight attendants. Furthermore, Brotheridge and Grandey (2002) found that the effect of SA on emotional exhaustion disappeared once the effect of other job-related variables and negative affect were controlled for. In view of this, some researchers argue that there is an indirect correlation between SA and burnout (e.g., Goodwin, 2011; Hülshegera \& Schewe, 2011). Since COR theory has identified the general underlying processes that lead to burnout, the present study builds upon this framework to explore the intervening variables in order to explain the correlation between SA and burnout. 
One of COR theory's key tenets is that the repeated experience of objective and perceived loss, or of the threat of loss, of resources in response to environmental demands will result in energy depletion (Hobfoll \& Shirom, 2001). Within customer service settings in the leisure industry, these demands are often related to how the employee ought to display specific emotions to customers. The perceived effort that is associated with this activity may be fundamental in explaining the resource loss process that eventually leads to employee burnout. In line with this, from a classic stress theory perspective, Quinones-Garcia, Rodriguez-Carvajal, \& Clarke (2013) developed a measure of the perceived effort involved in meeting display rules. In their validation study with a wide range of customer service employees, the authors found that perceived emotional effort explained the associations between SA and exhaustion, the key dimension of the burnout syndrome. Building upon COR, it is also expected that individuals who perceive themselves to be exerting a high degree of effort in faking the emotions that their job requires are likely to distance themselves from the customer in an attempt to avoid further resource loss. Therefore, it is hypothesized that emotional effort strongly correlates with the overall burnout syndrome.

\section{Hypothesis 1: Emotional effort is positively related to burnout.}

According to COR theory, the other fundamental and complementary process leading to burnout is the lack of resource recovery following investment. Consequently, even when situations require high resource investment, individuals can avoid burnout through successfully recovering the resources. However, engaging in SA is unlikely to help in the recovery process since, according to Côté (2005), the negative reaction of customers to employees' fake emotional displays further increases employee stress levels. Brotheridge and Lee (2002) reported evidence on the negative impact of SA on customers' interactions in customer service settings. Martínez-Íñigo, Totterdell, Alcover \& Holman (2007) have reported observing a similar negative impact within a health service context. The Effort-Reward Imbalance (ERI) perspective (Siegrist, 1996) supports the negative impact of customer reactions to fake displays on employees' emotional depletion. Therefore, employees may perceive that customer recognition does not offset the effort involved in meeting the job's emotional requirements. In the context of front-line line employees within the leisure industry, where the management of customer emotions is seen as a key to the success of the service transaction (Brunner-Sperdin \& Peters, 2009), employees' perceptions of the fair exchange between their own efforts and positive reactions from customers is likely to play a highly salient role in their psychological and physical wellbeing. In short, the present authors believe that the combined process of high effort involvement and low rewarding interactions with customers may explain the correlation between SA and burnout.

\section{Hypothesis 2: Emotional effort and rewarding interactions fully mediate the relationship between surface acting and burnout.}

Another tenet of COR theory is that an individual's available resources may buffer the negative consequences of excessive resource investment. The theory also predicts that when not experiencing stress, people invest resources to actively build up reservoirs that help them cope with future demands. For example, practising yoga within a mindfulness program requires a certain investment of physical energy, but in the long term, individuals can potentially improve their physical condition, learn to decrease adverse emotional reactions under high demands (i.e. high arousal) and learn to evoke a mindful mindset that allows them to deal more effectively with future demands (Van Gordon, Shonin, Zangeneh, \& Griffiths, 2014). Building upon this, Sonnentag and Fritz's (2007) work on psychological recovery from work-related stress suggests that for effective recovery, individuals need to invest resources in non-related work activities that lead to experiences of mastery, relaxation and/or or effective detachment from work (Sonnentag \& Fritz, 2007). Thus, the ability to engage in recovery experiences is expected to negatively relate to burnout.

\section{Hypothesis 3: Recovery ability negatively correlates with burnout.}

Based on the empirical evidence suggesting that recovery experiences improve wellbeing and allow for workrelated stress recovery, it is argued that these experiences could ameliorate the negative impact of emotional effort on burnout. Methodologically, some scholars consider this a moderated mediation effect (Muller, Judd \& Yzerbyt, 2005). In view of this:

\section{Hypothesis 4: Recovery ability moderates the mediating effect of emotional effort on the relationship between surface acting and burnout. Thus, at low recovery ability levels, the correlation between emotional effort and burnout will be higher than at high levels of recovery ability.}

Two field studies were conducted to investigate the four hypotheses. It was important to conduct the research in an organisational context where work-related emotion is particularly salient. As such, data were collected from theme park employees, where workers must actively participate with their emotions to create the fun atmosphere that is required within this environment. Although theme parks in two different countries (UK and Spain) were selected, the organisations had equivalent structures and both belong to large multinational entertainment chains. Study 1 tested Hypotheses 1 and 2 among UK employees, whilst Study 2 
tested Hypotheses 1 to 4 with Spanish employees. The study took a cross-national validation approach to test the proposed theoretical model. This approach enabled the research team to test whether the proposed mechanisms across countries (irrespective of the potential differences in the involved variable levels) could be generalised.

\section{Study 1}

\section{Method}

Recruitment and participants. The research team contacted the participating organisation's HR teams to request collaboration on a project studying work-related emotional skills and employee wellbeing. The companies were offered free consultation services upon completing the research project. A total of 203 employees working in a UK theme park chain participated in this study. Participants' ages ranged from 18 to 72 years old, with an average of 29 years of age. Of the sample, $36 \%$ were male and $64 \%$ were female. Participants had worked in customer service for an average of 8.3 years, and had spent an average of 3.9 years in the current organisation. They spent an average of nearly $80 \%$ of their working hours with customers.

Instruments. The surface acting subscale from Brotheridge and Lee (2003) was utilised to assess SA. Respondents were asked to rate the extent to which they engaged in each of the item statements when dealing with customers from $1=$ never to $5=$ always. A sample item included: «Hide my true feelings about a situation». Cronbach's alpha was .72. Burnout was assessed using Schaufeli, Leiter, Maslach and Jackson's (1996) Maslach Burnout Inventory (MBI) (1996). The scale comprises three subscales: emotional exhaustion (five items, e.g., «working all day is really a strain for me»); cynicism (five items, e.g., «I doubt the significance of my work), and professional efficacy (six items, e.g., «I have accomplished many worthwhile things in this job»). Respondents were asked to rate the extent to which they experienced each of the items in the statements from 1 = never to 5 = always. Cronbach's alpha was .89 for emotional exhaustion, .92 for cynicism, and .82 for professional efficacy.

To assess emotional effort, the Emotional Effort Scale (EES) (Quinones-Garcia et al., 2013) was utilised. This 7-item instrument measures the effort that occurs in the process of meeting the job's emotional requirements. It has two correlated dimensions: explicit

Table 1. Sociodemographic variables of the two samples

\begin{tabular}{lcc}
\hline & UK $(\mathrm{N}=\mathbf{2 0 3})$ & Spain $(\mathrm{N}=208)$ \\
\hline Gender (\% female) & 64 & 48 \\
Time spent with customers (\%) & 80 & 91 \\
Age (M,SD) & $29,10.4$ & $30,9.6$ \\
Years in Customer Service (M,SD) & $8.3,7.6$ & $8.4,8$ \\
Years in Current Organization (M,SD) & $3.9,4.8$ & $6.2,7$ \\
\hline
\end{tabular}

emotional effort (i.e., direct perceptions of the effort) and implicit effort (i.e., the degree of interference with other tasks). The scale employs a 5-point Likert scale where $1=$ never and $5=$ always. The instructions encouraged participants to think about the process through which they meet their job's emotional display rules (e.g., smiling when greeting a customer) and asked them how often they had experienced the feelings in the item statements. A sample item for explicit effort was: «How often have you felt that this activity involves a great amount of effort?» A sample item for implicit effort was: «How often have you felt that meeting emotional display rules impairs your performance on other tasks?» The Cronbach's alphas were .71 for explicit effort and 85 for implicit effort.

Rewarding interactions were assessed with Brotheridge and Lee's 4-item scale (2002). The scale employs a 5-point Likert Scale where $1=$ definitely true and 5 = definitely false. A sample item was: «I get very little thanks or recognition from my customers in return for my efforts». Cronbach's alpha was .85.

Since researchers have strongly associated shortterm negative mood with burnout, and state negative affect appears to mediate the impact of SA on withdrawal (e.g., Scott \& Barnes, 2011), the role of state negative affect in the hypothesised relationships was statistically controlled for. Watson, Clark and Tellegen's 10-item scale (1988) was utilised to ask respondents to rate the extent to which they were feeling each of the adjectives that described negative feelings and emotions at the present time. The responses are made on a five-point Likert scale from $1=$ not at all to $5=\mathrm{ex}-$ tremely. Cronbach's alpha was .86.

Data analysis. The goal of the study was to explain the relationships between the global constructs; therefore a latent variable model was used wherein each variable represented the global construct of study. This study's interest in overall constructs as opposed to subdimensions also aligns with mainstream research in the work-related emotion literature (e.g., Goldberg \& Grandey, 2007). Methodologically, this approach is warranted when the study's focus is on the relationship among overall constructs, as opposed to an interest in the measurement space's dimensionality at the item level (Little, Cunningham \& Shahar, 2002). Each latent variable's indicators were developed through the internal consistency item parcelling strategy. This strategy uses the mean of the items for each construct's dimension as indicators of their corresponding global construct (Little et al., 2002). This method has the advantage of preserving the constructs' multidimensional nature whilst keeping the main focus at the global level.

The measurement and structural models were tested using Structural Equation Modelling (SEM) and AMOS 20 software and model parameters were estimated with a maximum likelihood analysis. Various goodness of fit indices were used to assess the research model's fit: the $\chi^{2}$ divided by the degrees of freedom $\left(\chi^{2} / \mathrm{df}\right)$, the Incremental Fit Index (IFI), Goodness of 


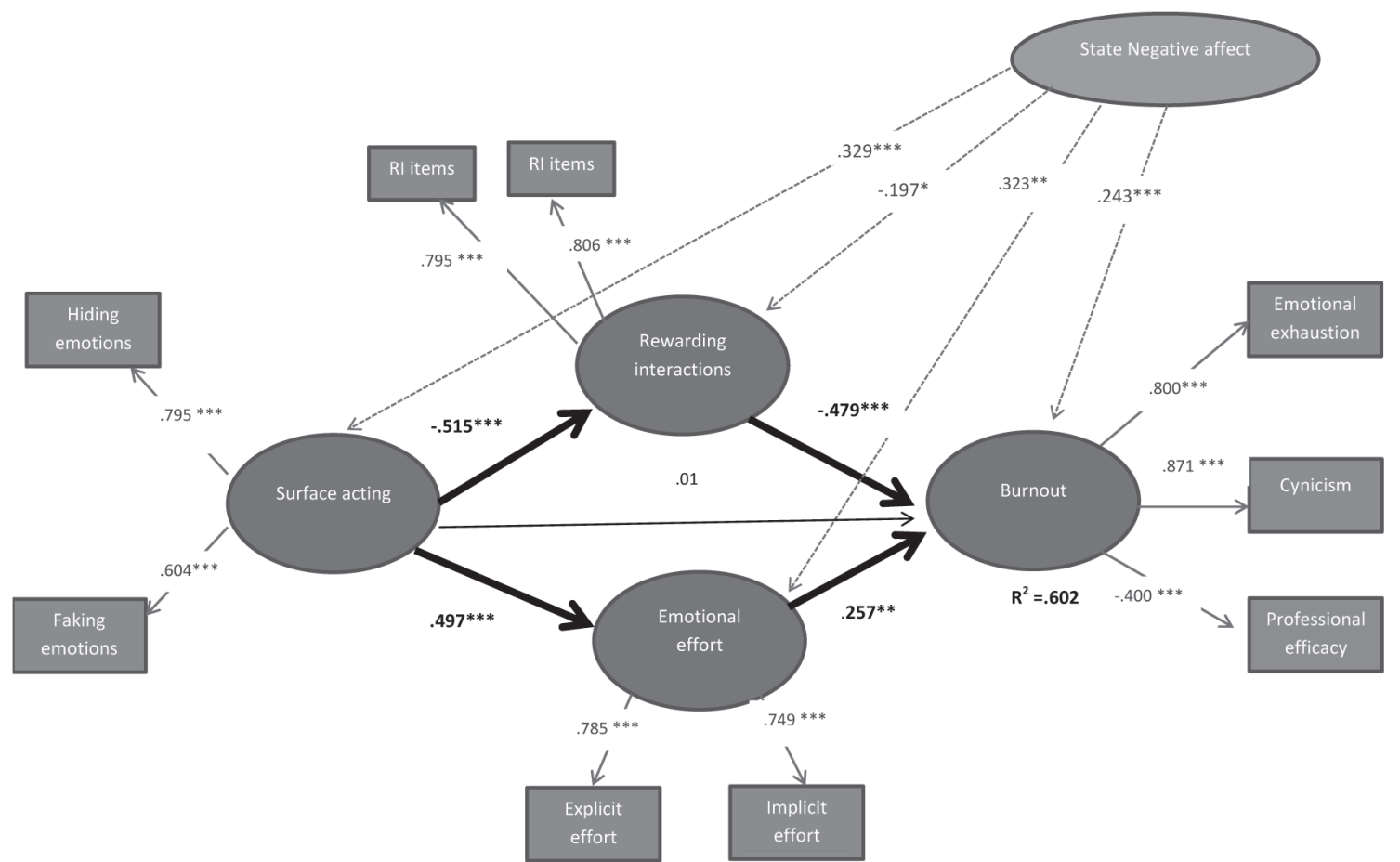

Figura 1a. Full Mediation Model and Standardized Path Coefficients (Study 1) Note: ${ }^{*} p<.05,{ }^{* *} p<.01,{ }^{* * *} p<.001$

Fit Index (GFI), the Comparative Fit Index (CFI), the Standardised Root Mean Square Residual (SRMR) and the Root Mean Square Error of Approximation (RMSEA). The recommended thresholds to assess model fit were as follows: the $\chi^{2} / d f$ value should be lower than 3 , the values of CFI, GFI and IFI should be above 9 . Finally, SRMR and RMSEA values below .10 and .05 indicated reasonable and good fit respectively (e.g., Hair, Anderson, Tatham \& Black, 1998). The mediation hypothesis was tested following James, Mulaik \& Brett's (2006) procedure with SEM. This method involves comparing the fit of a model that has a path from the independent variable to the dependent variable in the mediator's presence (i.e., partial mediation model), to one where that path is deleted (i.e., full mediation). The full mediation model's fit was compared to a partial mediation model whilst controlling for the influence of negative affectivity, which was modelled as an exogenous variable affecting all the latent variables (e.g., Markel \& Frone, 1998). The most parsimonious model was retained (i.e., full mediation model) unless comparison of fit between the two nested models suggested that the model with the added path had a significantly better fit.

\section{Results}

The main diagonal in Table 2a illustrates the correlations, means, and standard deviations of the study's main variables. As expected, burnout positively correlated with emotional effort, thus supporting Hypothesis $1(r=.622, p<.001)$. Similarly, emotional effort also correlated with SA $(r=.515, p<.001)$. This provided preliminary support for Hypothesis 2 .
Item parcels using the construct dimensions as indicators of the latent variables were developed. Subsequently, the measurement model's fit was tested including all study variables, and the model achieved a good fit (CFI=.965, GFI=.939, IFI=.966, SRMR=.04, RMSEA=.06). All indicators loaded significantly in the intended latent factors (see Figure 1a). In order to test the latent constructs' internal consistency, factor loadings were used to estimate construct reliability. These values were above the recommended threshold of 6 (Fornell \& Larcker, 1981).

Next, the structural model and the study's hypotheses were tested. Figure 1a highlights the standardised path coefficients. Hypothesis 1 was confirmed $(r=.257, p<.001)$. Hypothesis 2 predicted that emotional effort and rewarding interactions mediated the relationship between SA and burnout. Following James et al.'s (2006) procedure, full mediation as a baseline model was tested. This model included four paths, two from the independent variable (i.e., SA) to the mediators (i.e., emotional effort and rewarding interactions) and two from the mediators to the outcome (i.e., burnout). In contrast, the partial mediation model had an additional path from SA to burnout. Table $2 \mathrm{~b}$ presents the model fit indices. Although the partial mediation also showed acceptable fit, the differences between this and the mediation model were not statistically significant $\left(\Delta \chi^{2}(1)\right.$ $=0.40$, n.s.), and the AIC index of the full mediation model was lower than that of the partial one (AIC=147.8). Consequently, the full mediation model that aligned with the parsimonious principle was preferred. 
Table 2a. Mean, Standard Deviation and Correlations of the Variables in Study 1 (British sample)

\begin{tabular}{|c|c|c|c|c|c|c|c|}
\hline & $\boldsymbol{M}_{\mathrm{UK}}$ & $S D_{\mathrm{UK}}$ & 1 & 2 & 3 & 4 & 5 \\
\hline 1 Surface Acting & 2.12 & .58 & $(.70)$ & & & & \\
\hline 2 Effort & 2.06 & .63 & $.515^{\star \star *}$ & (.74) & & & \\
\hline 3 Rewarding interactions & 2.21 & .89 & $-.507^{* \star *}$ & $-.558^{\star \star \star}$ & $(.85)$ & & \\
\hline 4 Burnout & 2.09 & .73 & $.448^{\star \star *}$ & $.622^{\star * *}$ & $-.691^{\star \star \star}$ & (.73) & \\
\hline 5 State Negative Affect & 5.3 & .21 & $.311^{\star * *}$ & $.491^{\star * *}$ & $-.367^{* * *}$ & $.539^{* * *}$ & (.86) \\
\hline
\end{tabular}

Note: $\dagger p<.10,{ }^{*} p<.050,{ }^{* \star} p<.010,{ }^{* \star *} p<.001$. Construct reliabilities are presented into brackets

Table 2b. Measurement and Structural Models for the Resources Depletion-Recovery Model (Study 1: British Sample)

\begin{tabular}{|c|c|c|c|c|c|c|c|c|c|c|}
\hline Model Specification & $\chi^{2}$ & $d f$ & $\chi^{2} / d f$ & CFI & GFI & IFI & SRMR & RMSEA & $\Delta \chi^{2}(p)$ & AIC \\
\hline Measurement Model & 76.5 & 45 & 1.70 & .965 & .939 & .966 & .04 & .06 & --- & --- \\
\hline \multicolumn{11}{|l|}{ Structural Model } \\
\hline S1 Full Mediation & 85.8 & 47 & 1.82 & .957 & .933 & .958 & .05 & .06 & --- & 147.8 \\
\hline S2 Partial Mediation & 85.8 & 46 & 1.85 & .956 & .933 & .957 & .05 & .06 & $\begin{array}{l}.040 \\
\text { (N.S.) }\end{array}$ & 149.8 \\
\hline
\end{tabular}

Note: $\chi^{2}$ _Chi Square differences; $d f_{-}$Degrees of freedom; CFI_Comparative Fit Index; Goodness-of-Fit statistic (GFI); IFI_ Incremental Fit Index; SRMR Standardised Root mean Square Residual; RMSEA_Root Mean Square Error of Approximation. $\Delta \chi^{2}(p) \_$Increment of Chi Square and probability; N.S. _ $p>.05$.

\section{Study 2}

In Study 1 initial evidence was found that supports the hypothesis of the combined effect of the resources depletion-recovery process. Study 2 had two objectives. The first was to examine whether the model could be replicated using a sample from a different country, thus cross-validating the findings (Hypothesis 1-3). The second was to test the extent to which recovery ability moderated emotional effort's mediation effect (Hypothesis 4).

\section{Method}

Recruitment and participants. The same procedure as in Study 1 was followed. A total of 208 employees working in the theme park industry in Spain participated in the study (female $=48 \%$, male $=52 \%$ ). Participants' ages ranged from 17 to 61 years old (mean=30 years). Participants were recruited using the same procedure as in Study 1.

Instrument adaptation and measurement invariance. Because no Spanish version existed, a member of the research team who is a native Spanish speaker with high proficiency in English translated the items from Study 1 from English into Spanish. Following this, another author who is a native English speaker translated the items back into English and checked the translation (Grandey et al., 2005). Additionally, Measurement Invariance (MI) tests were conducted to ensure that the instruments were measuring the same constructs. In the context of cross-national research, lack of measurement invariance is just as threatening to the adequacy of a study's findings for hypothesis testing as the instruments' lack of reliability and validity would be (Vandenberg \& Lance, 2000). Although a latent variable approach with global constructs was used, the research team initially tested measurement invariance at the item level to limit model misspecification at the aggregate level (Little et al., 2002).

Measurement Invariance tests with Multigroup Confirmatory Factor Analysis were conducted using AMOS 20. The first level of invariance (i.e., configural invariance) was demonstrated by fitting the model simultaneously with two groups and showing a good model fit. The next level assessed metric invariance, the most fundamental test of measurement invariance across groups. If invariance holds here, then items convey the same meaning across different groups and the latent constructs underlying these items are comparable across groups (Cheung \& Rensvold, 2002). To support the invariance model with no constraints across groups (i.e., allowing factor loadings to vary freely across countries), it was compared to a model with the added constraint of equal factor loadings across samples. Since these are nested models, the $\chi^{2}$ difference test can be computed. A non-significant difference supports metric invariance. It should also be noted that full metric invariance is very rare, and that partial measurement invariance is more common. Nevertheless, many researchers argue that provided that one actually keeps the latter to a minority of items, group comparisons are not affected (Cheung \& Rensvold, 2002).

Lee and Brotherdige's SA subscale (2006) was translated into Spanish as no version existed. Cronbach's alpha was .76. A validated Spanish version of the Maslach Burnout Inventory (MBI) from Salanova, Schaufeli , Llorens, Peiro \& Grau (2000) was utilised to assess burnout. Cronbach's alpha was .92 for emotional exhaustion, .90 for cynicism, and .88 for professional efficacy. The Spanish version of the EES was utilised to assess emotional effort (Quinones-García et al., 2013). Cronbach's alpha was .75 for explicit effort and .80 for implicit effort. Rewarding interactions were measured 


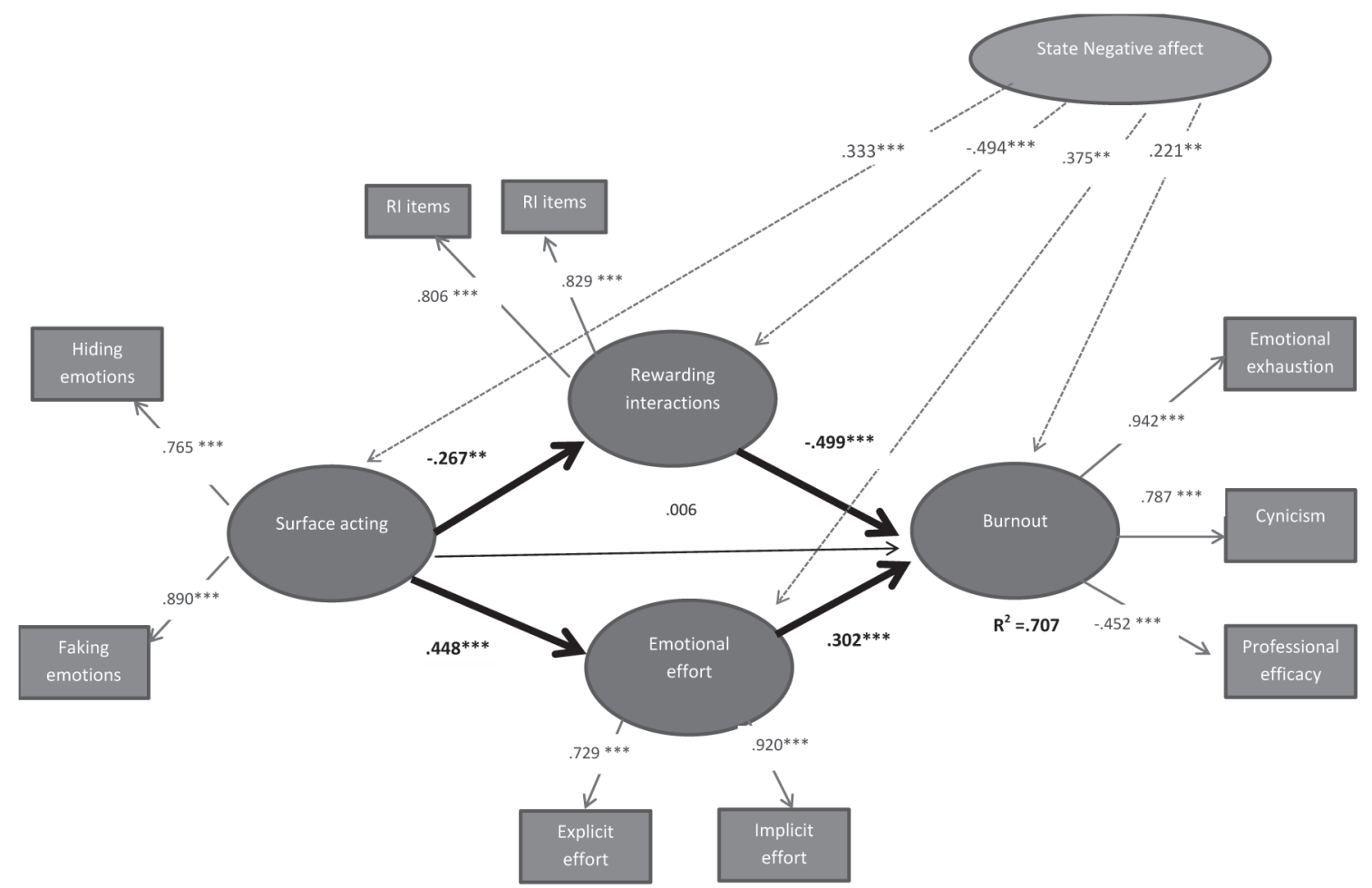

Figura 1b. Full Mediation Model and Standardized Path Coefficients (Study 2).

Note: ${ }^{\star} p<.05$, one tailed, ${ }^{* *} p<.01,{ }^{* * *} p<.001$

with Brotheridge and Lee's (2002) instrument. This was translated into Spanish and MI was tested. Cronbach's alpha was .88. The previously validated Spanish version of Watson et al.'s (1988) scale was utilised to assess negative affect. Cronbach's alpha was .84. Finally, recovery ability was assessed with a Spanish version of Sonnentag's scale (Moreno-Jiménez et al., 2009). This six-item scale includes items about relaxation, mastery and psychological detachment. A sample item was: «I'm able to switch off and relax after work». Respondents were asked to rate the extent to which they experienced each of the statements on a scale from $1=$ strongly disagree to $5=$ strongly agree. In this study, Cronbach's alpha was .82.

Data analysis. Hypotheses 1 and 2 were tested following the same strategy as described in Study 1. Hypotheses 3 and 4 were tested with Muller et al.'s (2005) moderated mediation procedure. In order to achieve this, the following conditions had to be met:

1. There is a significant effect of the predictor variable $(X)$ on the outcome variable $(Y)$ and the non-significant interaction effect between moderator and predictor variable $(X M o)$ with regards to the dependent variable $(Y)$. $\left(Y=\beta_{11} X+\beta_{12} M o+\beta_{13} X m o\right.$, where $\beta_{11} \neq 0$ and $\beta_{13}=0$ ).

2. There is an interaction effect between the moderator and predictor variable $(\mathrm{MoX})$ with the mediator variable as dependent variable (Med) or a significant effect between the predictor variable $(X)$ and the mediator variable $(\mathrm{Med}),\left(\mathrm{Med}=\beta_{31} X+\beta_{32} \mathrm{Mo}+\beta_{33}\right.$ $X M o+\beta_{34}$ Med $+\beta_{35}$ MedMo, where $\beta_{34}$ Med $\neq 0$ or $\beta_{35}$ MedMo $\neq 0$ ).

Depending on which betas were significant in the previous step, two conditions had to be met. First, if there was an interaction effect between the moderator and predictor $(M o X)$ in relationship with the mediator from the previous step, there must also be a significant effect of the mediator variable (Med) in the relationship with the criterion variable. Conversely, if in Step 2 the predictor variable was significant, then there must also be a significant interaction between the mediator and the moderator variable $(\mathrm{MedMo})$ with the criterion variable $(Y)\left(Y=\beta_{31} X+\beta_{32} M o+\beta_{33} X M o\right.$ $+\beta_{34}$ Med $+\beta_{35}$ MedMo, where $\beta_{34}$ Med $\neq 0$ or $\beta_{35}$ MedMo $\neq 0)$.

Finally, it should also be noted that these are the minimum requirements, but it is also moderated mediation when all four conditions from Steps 2 and 3 hold. Although it is likely that the interaction between the mediator and moderator holds, this is not a necessary condition to establish moderated mediation (Muller et al., 2005, p. 856). The hypothesis with an integrated moderated mediation analysis (using the PROCESS macro) was also tested and yielded similar results.

\section{Results}

Table 3 highlights the measurement invariance test results. The same internal consistency strategy was followed for item parcelling as in Study 1. The resulting measurement model achieved a good fit (CFI=.955, $\mathrm{IFI}=.956, \mathrm{GFI}=.933, \mathrm{SRMR}=.04, \mathrm{RMSEA}=.08$ ). Table $4 \mathrm{a}$ presents descriptive and bivariate correlations. The negative association between recovery ability and burnout confirms Hypothesis 3 ( $r=-.406, p<.001)$. 
Table 3. Measurement Invariance of the Study Instruments for the British Sample (Study 1) and the Spanish Sample (Study 2)

\begin{tabular}{|c|c|c|c|c|c|c|c|c|}
\hline Scale & $\begin{array}{l}\text { Model } \\
\text { Specification }\end{array}$ & $\chi^{2}(d f, p)$ & CFI & IFI & SRMR & $\Delta \chi^{2}$ & $\Delta \mathrm{CFI}$ & $\begin{array}{l}\text { Statistical } \\
\text { differences }\end{array}$ \\
\hline \multirow[t]{3}{*}{ Surface acting } & $\begin{array}{l}\text { Configural } \\
\text { Invariance }\end{array}$ & $\begin{array}{c}30.11 \\
(15 ; p<.05)\end{array}$ & .977 & .978 & .05 & --- & --- & --- \\
\hline & $\begin{array}{l}\text { Full Metric } \\
\text { Invariance }\end{array}$ & $\begin{array}{c}47.04 \\
(21 ; p<.05)\end{array}$ & .961 & .962 & .05 & $\begin{array}{c}16.93 \\
(\mathrm{p}<.05)\end{array}$ & .01 & Significant \\
\hline & $\begin{array}{l}\text { Partial Metric } \\
\text { Invariance* }\end{array}$ & $\begin{array}{c}38.89 \\
(19 ; p<.05)\end{array}$ & .970 & .971 & .05 & $\begin{array}{c}8.67 \\
(\mathrm{p}=.071)\end{array}$ & .01 & Not significant \\
\hline \multirow[t]{2}{*}{ Emotional effort } & $\begin{array}{l}\text { Configural } \\
\text { Invariance }\end{array}$ & $92(24 ; p<.05)$ & .943 & .944 & .03 & --- & --- & --- \\
\hline & $\begin{array}{l}\text { Full Metric } \\
\text { Invariance }\end{array}$ & $\begin{array}{c}102.4 \\
(29 ; p<.05)\end{array}$ & .939 & .939 & .04 & $\begin{array}{c}10.41 \\
(p=.060)\end{array}$ & .00 & Not significant \\
\hline \multirow[t]{2}{*}{$\begin{array}{l}\text { Rewarding } \\
\text { interactions }\end{array}$} & $\begin{array}{l}\text { Configural } \\
\text { Invariance }\end{array}$ & $\begin{array}{c}12.10 \\
(4 ; p<.05)\end{array}$ & .990 & .990 & .01 & --- & --- & --- \\
\hline & $\begin{array}{l}\text { Full Metric } \\
\text { Invariance }\end{array}$ & $\begin{array}{c}14.85 \\
(7 ; p<.05)\end{array}$ & .990 & .990 & .01 & $\begin{array}{c}2.75 \\
(\mathrm{p}=.441)\end{array}$ & .00 & Not significant \\
\hline \multirow[t]{2}{*}{ Burnout } & $\begin{array}{l}\text { Configural } \\
\text { Invariance }\end{array}$ & $\begin{array}{c}421.2 \\
(192 ; p<.05)\end{array}$ & .960 & .960 & .06 & --- & --- & --- \\
\hline & $\begin{array}{l}\text { Full Metric } \\
\text { Invariance }\end{array}$ & $\begin{array}{c}461.7 \\
(205 ; p<.05)\end{array}$ & .960 & .960 & .06 & $\begin{array}{c}.42 \\
(\mathrm{p}=.514)\end{array}$ & .00 & $\begin{array}{c}\text { Not } \\
\text { Significant }\end{array}$ \\
\hline \multirow[t]{3}{*}{ Negative Affect } & $\begin{array}{l}\text { Configural } \\
\text { Invariance }\end{array}$ & $\begin{array}{c}184.1 \\
(65, p<.05)\end{array}$ & .929 & .930 & .06 & --- & --- & --- \\
\hline & $\begin{array}{l}\text { Full Metric } \\
\text { Invariance }\end{array}$ & $\begin{array}{c}213.9 \\
(71, p<.05)\end{array}$ & .891 & .892 & .08 & $\begin{array}{c}61.8 \\
(\mathrm{p}<.05)\end{array}$ & .03 & Significant \\
\hline & $\begin{array}{l}\text { Partial Metric } \\
\text { Invariance* }\end{array}$ & $\begin{array}{c}169.9 \\
(69, p<.05)\end{array}$ & .927 & .928 & .05 & 7.3 & .00 & Not significant \\
\hline
\end{tabular}

Note: Partial Metric Invariance* most items were invariant. $\chi^{2}$ _ Chi Square differences; $d f$ _Degrees of freedom; CFI_Comparative Fit Index; IFI_Incremental Fit Index; SRMR Standardised Root mean Square Residual; $\Delta \chi 2(p) \_$Increment of Chi Square; $\Delta$ CFI_Increment Comparative Fit Index

Subsequently, the structural model and the model fit indices were tested (see Table $4 \mathrm{~b}$ ). Figure $1 \mathrm{~b}$ shows the standardised path coefficients. In line with the results that were obtained in Study 1 , emotional effort significantly related to burnout $(\beta=.302, p<.001)$, thus supporting Hypothesis 1. Furthermore, emotional effort and rewarding interactions fully mediated the relationship between SA and burnout, further supporting Hypothesis 2. As shown in Tables 4a and 5, Hypothesis 3 was also confirmed, meaning that recovery ability was negatively related to burnout.

The moderated mediation effects were initially tested with the study's global constructs and no significant effects were found. Since the global constructs (burnout and emotional effort) were multidimensional, moderated mediation tests were conducted independently for each dimension of the constructs in order to rule out any unique effects at this level. It was found that recovery ability significantly moderated the mediation effect of implicit effort on the relationship between surface acting and emotional exhaustion (see Table 5). Therefore, initially, the relationship between SA and exhaustion was significant, and there was a lack of significant correlation of the interaction between the predictor and moderator variables. Surface acting significantly correlated with the mediator variable when it was introduced to the latter as a dependent variable. Finally, the interaction between the mediator and the moderator was significant and the Sobel test confirmed a reduction in the significant coefficient for surface acting. Therefore, partial moderated mediation was confirmed $(z=2.54 ; p<.001)$.

In order to aid in the interpretation of this moderated mediation effect, Cohen et al.'s simple slope test (2003) was applied. At high levels of recovery ability, the correlation between implicit emotional effort and exhaustion was not significant $(b=.125 ; t=1.745$; $p=$ .085). However, at low levels of recovery ability, the correlation was positive and significant $(b=.299 ; t=$ 4.197; $p<.001)$. With regards to explicit emotional effort, all conditions were met except for the last one, as the interaction between the mediator and the moderator was not significant at $.05(b=.098 ; p=.068)$. Therefore, moderated mediation with the explicit effort dimension was not supported. In view of this, Hypothesis 4 was only confirmed for the implicit effort dimension (i.e., only partial support was found).

\section{General Discussion}

The objectives of the present study were twofold: (i) to develop and test the resources depletion-recovery process, and (ii) to cross-nationally validate this model across two countries (UK and Spain) with different traditions regarding «service with a smile». Building on COR theory, the mechanisms were identified that 
Table 4a. Mean, Standard Deviation and Correlations of the Variables in Study 2 (Spanish sample)

\begin{tabular}{|c|c|c|c|c|c|c|c|c|}
\hline & $M_{\text {spain }}$ & $S D_{\text {spain }}$ & 1 & 2 & 3 & 4 & 5 & 6 \\
\hline 1 Surface Acting & 1.92 & .53 & $(.81)$ & & & & & \\
\hline 2 Effort & 2.50 & .85 & $.553^{\star *}$ & $(.82)$ & & & & \\
\hline 3 Rewarding interactions & 2.75 & 1.11 & $-.420 * * *$ & $-.706^{\star * *}$ & $(.82)$ & & & \\
\hline 4 Burnout & 1.64 & .92 & $428^{\star \star \star}$ & $.691^{\star * \star}$ & $-.800^{* * *}$ & $(.78)$ & & \\
\hline 5 State Negative Affect & 5.19 & 0.20 & $.329 * * *$ & $.523^{* * *}$ & $-.600^{* * *}$ & $.655^{* * *}$ & $(.84)$ & \\
\hline 6 Recovery ability & 4.26 & .70 & $-.174^{*}$ & $-.215^{\star *}$ & $.350 * * *$ & $-.406^{\star * *}$ & $-.248 * * *$ & $(.82)$ \\
\hline
\end{tabular}

Note: $\dagger p<.10,{ }^{*} p<.050,{ }^{* *} p<.010,{ }^{* \star *} p<.001$. Construct reliabilities are presented into brackets

Table 4b. Measurement and Structural Models for the Resources Depletion-Recovery Model (Study 2: Spanish Sample)

\begin{tabular}{lccccccccccc}
\hline Model Specification & $\chi 2$ & $d f$ & $\chi 2 / d f$ & CFI & GFI & IFI & SRMR & RMSEA & $\Delta \chi^{2}(p)$ & AIC \\
\hline Measurement Model & 95.8 & 41 & 2.33 & .955 & .933 & .956 & .04 & .08 & --- & & \\
Structural Model & & & & & & & & & \\
S1 Full Mediation & 101.1 & 35 & 2.88 & .945 & .918 & .946 & .06 & .09 & --- & 163.1 \\
S2 Partial Mediation & 101.1 & 34 & 2.97 & .944 & .918 & .945 & .06 & .09 & .05 (N.S.) & 165.1 \\
\hline
\end{tabular}

Note: $\chi 2$ _ Chi Square differences; $d f \_$Degrees of freedom; CFI_Comparative Fit Index; Goodness-of-Fit statistic (GFI); IFI_Incremental Fit Index; SRMR Standardised Root mean Square Residual; RMSEA_Root Mean Square Error of Approximation. $\Delta \chi 2$ ( $p)_{-}$Increment of Chi Square and probability; N.S. _ $p>.05$.

ultimately explain the emotional depletion process that occurs when the occupational role requires faking emotions (i.e., emotional effort and unrewarding customer interactions). Furthermore, it was found that individuals' ability to engage with recovery experiences after work were able to mitigate the impact of the effort that occurs with faking emotions. Since measurement invariance confirmed that the instruments were measuring equivalent constructs in both the UK and Spain, the cross-national validation process results offer strong support that the identified mechanisms are key to understanding the correlation between SA and burnout in these two countries.

Initially, Anglo-Saxon studies dominated the workrelated emotion literature in the leisure industry and in other service sectors. However, in recent years, there have been increasing numbers of studies from Europe and Asia. Examples include Grandey et al.'s French study (2005), Allen et al.'s Chinese study, and Bozionelos and Kiamou's Greek study (2008). By incorporating a Spanish sample, this study also contributes to the understanding of how work-related emotion affects employees' psychological and physical wellbeing in a national context where the «service with a smile» concept has had a shorter lifespan than in the AngloSaxon culture. In spite of these differences, and in line with the other Latin-European studies, the study also confirmed that faking emotions is equally costly to individuals in these countries (e.g., Zammuner \& Galli, 2005). Cross-national studies that explicitly ad-

Table 5. Moderated mediation effect of Recovery Ability on the relationship between Surface Acting and Emotional Exhaustion (Burnout)

\begin{tabular}{|c|c|c|c|}
\hline \multirow{2}{*}{$\frac{\text { Model Summary }}{\text { Standardised coefficients }}$} & \multicolumn{3}{|c|}{ Dependent variables } \\
\hline & Exhaustion & Effort (implicit) & Exhaustion (burnout) \\
\hline Step 1: Control Vbs. $\left(\Delta R^{2}\right)$ & $\left(.425^{\star * *}\right)$ & $\left(.147^{\star \star \star}\right)$ & $\left(.425^{\star \star *}\right)$ \\
\hline Age & .125 & -.004 & .126 \\
\hline Gender & .017 & .010 & .011 \\
\hline Negative Affectivity & .547 & $.304^{* * *}$ & $.483^{* * *}$ \\
\hline Step 2: $\mathrm{X}\left(\Delta R^{2}\right)$ & $\left(.035^{* * *}\right)$ & $\left(.077^{\star \star \star}\right)$ & $\left(.035^{\star * \star}\right)$ \\
\hline Surface acting & $.179^{\star \star *}$ & $.291^{* \star *}$ & $.113^{*}$ \\
\hline Step 3: Mo $\left(\Delta R^{2}\right)$ & $\left(.033^{\star \star *}\right)$ & $(.001)$ & $\left(.033^{\star \star \star}\right)$ \\
\hline Recovery ability & $-.191^{* *}$ & .023 & $-.201^{* *}$ \\
\hline Step 4: XMo $\left(\Delta R^{2}\right)$ & $(.001)$ & $(.001)$ & $(.001)$ \\
\hline Surface acting *Recovery ability & -.035 & -.034 & -.077 \\
\hline Step 5: Med and MedMo $\left(\Delta R^{2}\right)$ & & & $\left(.047^{\star \star \star}\right)$ \\
\hline Effort (implicit) & & & $.210^{\star * *}$ \\
\hline Effort (implicit) ${ }^{\star}$ recovery ability & & & $.118^{*}$ \\
\hline Adjusted $R^{2}$ & & & .52 \\
\hline
\end{tabular}

Note: $\dagger p<.10 .{ }^{*} p<.050 .{ }^{* *} p<.010 .{ }^{* *} p<.001 . X \_$Independent variable; Mo_Moderator; XMo_Interaction between moderator and independent variable; MedMo_Interaction between Mediator and Moderator 


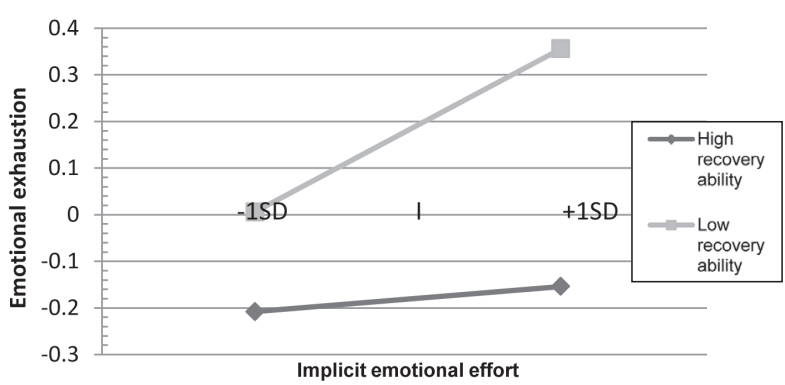

Figura 2. Moderated mediation effect of Recovery Ability on the relationship between Surface Acting and Emotional Exhaustion (Burnout) (Study 2)

dress the underlying psychological mechanisms across different countries are scarce. Within a globalised service-based economy with a high level of multinational employment, understanding the impact that specific job demands have on employees' productivity and health across different national backgrounds is of paramount importance. The cross-national model testing approach in the present study led to the conclusion that regardless of differences in levels of use of EL across countries, the psychological mechanisms underlying the link between SA and burnout may be the same in both Spanish and British employees in the leisure industry. Thus, the study provides preliminary evidence that in both countries faking the emotions that the job requires can result in a dangerous net resource loss due to a combined mechanism of high effort investment and a lack of customer recognition, thus impeding the resources recovery process.

Findings from the present study also provide some support for the positive impact of distal resources recovery processes, which may serve to lessen burnout symptoms. Following COR, recovery experiences were conceptualised as resource investment activities to the extent to which they could alleviate the negative impact of resource depletion on burnout. More specifically, it was found that recovery experiences moderated the negative impact that implicit effort had on emotional exhaustion. Consequently, the higher the recovery ability individuals reported, the lower the interference with other tasks they would perceive when performing work-related emotion via SA. These findings are in line with other phenomena that others have presented in the recovery literature (e.g., Sonnentag \& Fritz, 2007). However, it should be noted that the study's results show that the moderated mediation was only significant for implicit effort and not for explicit effort. One potential explanation for these differences may be to do with the direct appraisal of these processes. Unlike explicit effort, implicit effort refers to a less consciously perceived effort that can be estimated by the degree of interference that work-related emotion has with other tasks. Similarly, the result of a successful recovery process may not necessarily be a consciously observed event, yet could still be one that provides employees with the resources to face a hard work day. This merits further study, ideally from a time-series design that incorporates the assessment of the effect of recovery on daily levels of emotional effort and strain. Nevertheless, the present study has identified alternative routes to ease the impact of effort should other means be unable to reduce it.

Among the study's limitations is common method bias. Nevertheless, Conway and Lance's (2010) steps were followed to minimise this risk. For instance, measures with good construct validity were used by ensuring that the measurement model had a good fit for each construct of study, and items loaded in their respective latent variables. Furthermore, the research team tried to minimise common method bias problems in the study's design by minimising social desirability (e.g., highlighting that questionnaires were confidential and anonymous). Additionally, there are inherent limitations to the cross-sectional nature of the study. Nevertheless, the consistency of the mediation effects in two independent samples provides strong evidence for the sequential order that was proposed in the theoretical model.

Additionally, the choice of item parcel and global construct analyses could be a threat to model misspecification. Nevertheless, since the data were modelled at the item level when conducting multidimensional and measurement invariance tests prior to item parcelling, the risk was minimised (e.g., Little et al., 2002). Finally, Hypothesis 4 refers to global effects, whereas moderated mediation tests were only significant for sub-dimensions that could be perceived as capitalization on chance. However, the results offer important insights that merit further study. Future investigation with time series and longitudinal methodology is also required to confirm the sequential development of the process. In particular, time series studies can help to analyse the immediate (rather than the aggregate) effects of rewarding interactions with customers and emotional effort and to identify alternative strategies for resources recovery.

Given that the job role's emotional requirements can be difficult to avoid in customer interactions within the leisure field, a number of practical implications can be derived from the present study. First, Human Resources should assess individuals' differences to the extent to which they perceive high effort in meeting display rules at the recruitment stage. Second, in order to maintain work-life balance and in view of the positive consequences of recovery ability, there is a need for organizational intervention in breaking up resource loss cycles at work and encouraging resource gain. Correspondingly, it is the organization's responsibility to ensure that it distributes working hours in such a way that their employees still benefit from quality time off work, especially in the leisure sector where employees tend to work shifts. By doing this, organisations demonstrate concern for employees' physical and psychological health and minimize the potentially harmful consequences of so-called «service with a smile».

The cross-nationally validated resources depletionrecovery model moves the attention beyond SA (which 
is a more distal correlate of burnout) and clearly identifies the variables that account for employees' exhaustion in roles where work-related emotion is highly salient. By having more accurate explanations of the exhaustion that occurs in the process of meeting the job role's emotional requirements, managers are better equipped to develop sound interventions that help prevent these problems from occurring in the first place.

Acknowledgements: The project design was supported by a Fundesfor PhD scholarship granted to the first author. The data collection in Spain was supported by Abbey Santander bursary.

\section{References}

Allen, J. A., Diefendorff, J. M., \& Ma, Y. (2014). Differences in emotional labor across cultures: A comparison of Chinese and US service workers. Journal of Business and Psychology, 29(1), 21-35.

Bozionelos, N. \& Kiamou, K. (2008). Emotion work in the Hellenic frontline services environment: How it relates to emotional exhaustion and work attitudes. International Journal of Human Resource Management, 19(6), 1108-1130. doi: 10.1080/09585190802051410 Brotheridge, C. M. \& Grandey A. A. (2002). Emotional labor and burnout: comparing two perspectives of people work. Journal of Vocational Behavior, 60(1), 17-39. doi: 10.1006/jvbe.2001.1815

Brotheridge, C. M. \& Lee R T. (2002). Testing a conservation of resources model of the dynamics of emotional labor. Journal of Occupational Health Psychology, 7(1), 57-67. doi: 10.1037/1076-8998.7.1.57

Brotheridge, C. M. \& Lee, R. T. (2003). Development and validation of the Emotional Labour Scale. Journal of Occupational and Organizational Psychology, 76(3),365-379. doi: 10.1348/096317903769647229

Brunner-Sperdin, A. \& Peters, M. (2009). What influences guest's emotions? The case of high quality hotels. International Journal of Tourism Research, 11, 171-183.

Cheung, G. W. \& Rensvold, R. B. (2002). Evaluating goodness-of-fit indexes for testing measurement invariance. Structural Equation Modelling, 9, 233-255. doi: 10.1207/S15328007SEM0902_5

Cohen, J. Cohen, P., West, S. G. \& Aiken, L. S.(2003). Applied multiple regression/correlation analysis for the behavior sciences. London: Lawrence Erlbaum.

Conway, J.M. \& Lance, C. E. (2010). What reviewers should expect from authors regarding common method bias in organizational research. Journal of Business and Psychology, 25, 325-334. doi: 10.1007/ s10869-010-9181-6

Côté, S. (2005). A social interaction model of the effects of emotion regulation on work strain. Academy of Management Review, 30(3), 509-530. doi:10.5465/ AMR.2005.17293692

Fornell, C. \& Larcker, D. G. (1981). Evaluating structural equation models with unobservable variables and measurement error. Journal of Marketing Research,
18, 39-50. doi:10.2307/3151312

Goldberg, L. S., \& Grandey, A. A. (2007). Display rules versus display autonomy: Emotion regulation, emotional exhaustion, and task performance in a call center simulation. Journal of Occupational Health Psychology, 12(3), 301-318.

Goodwin, R. E. (2011). Understanding the relationship between emotional labor and effort. In C. E. J. Hartel, N. M. Ashkanasy \& W. J. Zerbe (Eds.), Research on emotions in organizations: What have we learned? Ten years on (pp. 45-71). Bingley: Emerald Group Publishing.

Grandey, A. A. (2015). Smiling for a Wage: What Emotional Labor Teaches Us About Emotion Regulation. Psychological Inquiry, 26(1), 54-60.

Grandey, A. A., Fisk, G. M., \& Steiner, D. D. (2005). Must «service with a smile» be stressful? The moderating role of personal control for American and French employees. Journal of Applied Psychology, 90(5), 893-904. doi:10.1037/0021-9010.90.5.893

Grandey, A. A., Rupp, D., \& Brice, W. N. (2015). Emotional labor threatens decent work: A proposal to eradicate emotional display rules. Journal of Organizational Behavior, 36,6, 770-785.

Groth, M., Hennig-Thurau, T., \& Walsh, G. (2009). Customer reactions to emotional labor: The roles of employee acting strategies and customer detection accuracy. Academy of Management Journal, 52(5), 958974.

Guy, M.E., Newman, M.A., \& Mastracci, S.H. (2014). Emotional Labor: Putting the Service in Public Service. London:Routledge.

Hair, J. F. Jr, Anderson, R. E., Tatham, R. L., \& Black, W. C. (1998). Multivariate data analysis (5th ed). New Jersey: Prentice Hall.

Han, S.J., Bonn,M.A., \& Cho, M.(2016). The relationship between customer incivility, restaurant frontline service employee burnout and turnover intention. International Journal of Hospitality Management, 52, 97-106. doi:10.1016/j.ijhm.2015.10.002"10.1016/j. ijhm.2015.10.002

Hobfoll, S. E. \& Shirom, A. (2001). Conservation of resources theory: Applications to stress and management in the workplace. In T. Golembiewski (Ed.), Handbook of organization behaviour (pp.57-81). New York: Marcel Dekker.

Hülshegera, U. R., \& Schewe, A. F. (2011). On the costs and benefits of emotional labor: A meta-analysis of three decades of research. Journal of Occupational Health Psychology, 16(3), 361-389. doi: 10.1037/ a0022876

James, L. R., Mulaik, S. A., \& Brett, J. M. (2006). A tale of two methods. Organizational Research Methods, 9(2), 233-244. doi: 10.1177/1094428105285144

Karatepe, O. M. \& Uludag, O. (2008). Role stress, burnout and their effects on frontline hotel employees' job performance: Evidence from Northern Cyprus. International Journal of Tourism Research, 10, 111-126.

Lee, R. T., \& Brotheridge, C. M. (2006, August). Validation and extension of the emotional labor scale: Eviden- 
ce from daycare workers. Paper presented at the EMONET conference, Atlanta.

Little, T. D., Cunningham, W. A., \& Shahar, G. (2002). To parcel or not to parcel: Exploring the question, weighing the merits. Structural Equation Modelling, 9(2), 151-173. doi: 10.1207/S15328007SEM0902_1

Markel, K.S., \& Frone, M. R. (1998). Job characteristics, work-school conflict, and school outcomes among adolescents: Testing a structural model. Journal of Applied Psychology, 83, 277-287. doi: 10.1037/00219010.83.2.277

Martínez-Iñigo, D., Totterdell, P., Alcover, C. M. \& Holman, D. (2007). Emotional labour and emotional exhaustion: Interpersonal and intrapersonal mechanisms. Work and Stress, 21(1), 30-47. doi: 10.1080/ 02678370701234274

Moreno-Jiménez, B., Mayo, M., Salovey, P., Sanz-Vergel, A. I., Geurts, S., Rodríguez-Muñoz, A., \& Garrosa, E. (2009). Effects of work-family conflict on employees' well-being: the moderating role of recovery strategies. Journal of Occupational Health Psychology, 14(4), 427 440.

Muller, D., Judd, C. M., \& Yzerbyt, V. Y. (2005). When moderation is mediated and mediation is moderated. Journal of Personality and Social Psychology, 89, 852863. doi: 10.1037/0022-3514.89.6.852

Quinones-Garcia, C., Rodríguez-Carvajal, R, \& Clarke, N. (2013). Development and cross-national validation of the Emotional Effort Scale (EEF). Psicothema, 25, 363-369. doi: 10.7334/psicothema2012.289

Salanova, M., Schaufeli ,W. B., Llorens, S., Peiro, J. M. \& Grau, R. (2000). Desde el «burnout» al «engagement»: ¿una nueva perspectiva? [From «burnout» to «engagement»: A new perspective?]. Revista de Psicología del Trabajo y las Organizaciones, 16, 117-134.

Schaufeli, W. B., Leiter, M. P., Maslach, C. \& Jackson, S. E. (1996). Maslach Burnout Inventory-General Survey (MBI-GS) (3 $3^{\text {rd }}$ Ed.). California: Consulting Psychologists Press.

Scott, B. A. \& Barnes C M. (2011). A multilevel field investigation of emotional labour, affect, work withdrawal and gender. Journal of Management, 54, 116136.

Siegrist, J. (1996), Adverse health effects of high-effort/ low-reward conditions. Journal of Occupational Health Psychology, 1, 27-41. doi: 10.1037/1076-8998.1.1.27

Sonnentag, S. \& Fritz, C. (2007). The recovery experience questionnaire: Development and validation of a measure for assessing recuperation and unwinding from work. Journal of Occupational Health Psychology, 12(3), 204-221. doi: 10.1037/10768998.12.3.204

Vandenberg, R. J. \& Lance, C. E. (2000). A review and synthesis of the measurement invariance literature:
Suggestions, practices, and recommendations for organizational research. Organizational Research Methods,3, 4-70. doi: 10.1177/109442810031002

Van Gordon, W., Shonin, E., Zangeneh, M., \& Griffiths, M. D. (2014). Can mindfulness really improve workrelated mental health and job performance? International Journal of Mental Health and Addiction, 12, 129-137. doi: 10.1007/s11469-014-9484-3

Watson, D., Clark, L. A. \& Tellegen, A. (1988). Development and validation of brief measures of positive and negative affect: The PANAS scales. Journal of Personality and Social Psychology, 54, 1063-1070. doi: 10.1037/0022-3514.54.6.1063

Zammuner, V. L. \& Galli, C. (2005). Wellbeing: Causes and consequences of emotion regulation in work settings. International Review of Psychiatry, 17(5), 355364. doi: 10.1080/09540260500238348

Zerbe, W. J. (2000). Emotional dissonance and employee well-being. In N. M. Ashkanasy, C. E. J. Hartel and W. J. Zerbe (Eds.), Emotions in the workplace: Research, theory and practice (pp. 189-192). Westport, CT: Quorum Boo.

Validación transnacional del modelo de recuperación de recursos desgastados: Un estudio empírico de empleados españoles y británicos de parques temáticos

Resumen. La actuación superficial (AS) se define como una estrategia en el que los empleados de cara al público esconden sus verdaderas emociones y simulan las emociones que se esperan de ellos en sus papeles de atención al cliente. Aunque investigadores anteriores han asociado la actuación superficial con el burnout (o síndrome de desgaste profesional), estudios recientes sugieren que esta relación puede ser indirecta. Basado en la Teoría de la Conservación de Recursos, se planteó la hipótesis que el efecto cumulado del esfuerzo emocional y la falta de interacciones gratificantes con los clientes, provocados por el recurso a AS, explicarían la asociación fuerte entre AS y el burnout (Estudios 1 y 2). Además, basado en la literatura psicológica sobre la recuperación, se planteó la hipótesis que el esfuerzo requerido por AS determinaría en menor grado el agotamiento de los empleados de cara al público en los casos en los que se atribuían niveles más altos de capacidad de recuperación que en los casos de niveles más bajos (Estudio 2). Se empleó un diseño transnacional y transversal, y los participantes fueron empleados de parques temáticos del Reino Unido (Estudio 1, $N_{U K}=204$ ) y España (Estudio 2, $N_{\text {Spain }}=211$ ). Se encontró evidencia del papel explicativo del esfuerzo emocional $y$ las interacciones gratificantes, y se confirmó el efecto amortiguador de la capacidad para la recuperación. Se comentan las estrategias diseñadas para minimizar el riesgo de burnout para los empleados que trabajan de cara al público en estos países.

Palabras clave: actuación superficial; esfuerzo emocional, interacciones gratificantes; burnout; transnacional 